\title{
Forestry Canada's International Relations
}

\author{
by
}

\author{
G.A. Steneker ${ }^{1}$
}

\section{Abstract}

The article outlines Forestry Canada's mandate and its role in international relations together with those of other federal departments and agencies.

For its international program, the Department has identified six objectives which deal with trade, science, development aid, policy, intelligence and the environment. Approaches are described to achieve each of these objectives.

\section{Résumé}

Cet exposé souligne le mandat de Forêts Canada et ses relations internationales en outre celui des autres ministères et des agences.

Forêts Canada a identifié six objectifs dans son programme international. Ils touchent au commerce, à la science, à l'aide, à la politique, à l'information et au milieu. objectifs.
As the focal point at the federal level for matters pertaining to forestry and forest resource development, Forestry Canada and its predecessor, the Canadian Forestry Service, has for many years maintained an international forestry relations program. This program has reflected the role and responsibilities of Forestry Canada and its predecessor, which underwent many transformations in structure and mandate, in response to changing economic, social, environmental, technological and political circumstances.

Forestry Canada's federal role in the forest sector has most recently been set out in the Department of Forestry Act which was officially proclaimed in January 1990. The Act empowers Forestry Canada to provide national leadership through coordination of the development and implementation of federal forest policies and programs; to enhance the utilisation of Canada's forest resources and the competitiveness of Canada's forest sector domestically and internationally through the development of scientific and technical capabilities in forest management, as well as the development and application of forest management codes and standards.

The federal focus for forestry rests with Forestry Canada. However, other federal departments also carry out forestry-related activities. The more important departments involved at the international level are the Department of External Affairs, which is responsible for trade relations and developing international markets for Canada's forest products; Industry, Science and Technology, which promotes the forest sector through marketing and industrial development programs; Agriculture Canada, which regulates the import and export of plant products to protect the health of Canada's forests; Environment Canada, which monitors

\footnotetext{
Director International Forestry Division, Forestry Canada, Ottawa K1A 1 G5
}

atmospheric pollution; the Canadian International Development Agency (CIDA), which assists developing countries in managing their forests; and the International Development Research Centre (IDRC) which supports scientific and technical research in forestry in developing countries.

The federal government's involvement in forestry at the international level is multifacetted: from representation on various committees, to memberships in government and nongovernmental organizations, to bilateral agreements with selected countries, to scientific exchange and technological transfer. The Canadian government also provides over $\$ 100$ million annually to developing nations through forestry assistance projects.

The establishment of Forestry Canada as a full federal department has provided a broader scope for international involvement and has brought about the need to review the department's international activities. The early emphasis on scientific cooperation information exchange has shifted and increased attention is being given to international market development and analysis.

\section{Program Objectives}

As part of the review, strategic guidelines for international involvement have been developed and a number of objectives have been identified. These are:

1. Enhance the competitiveness of Canada's forest sector in world markets:

- by assisting the Departments of External Affairs and Industry, Science and Technology and the Canadian forest industry in identifying opportunities to promote Canada's forest products and related technology in world markets 
through trade missions and market development programs; and

- by assisting the federal government in formulating trade policies and defending Canadian forestry interests.

\section{Promote and enhance Canada's forestry science;}

- by promoting the excellence of Canada's forestry research through exchange programs, co-operative agreements and study tours with other countries;

- by developing opportunities to access emerging and rapidly developing technologies through bilateral agreements with other countries, international meetings and research contacts with international organizations; and

- by assisting the federal government in formulating science policies to address Canadian and global concerns.

3. Increase Canada's assistance to developing forestry nations;

- by increasing the scope of Forestry Canada's participation in Canada's Official Development Assistance programs by planning and executing selected forestry projects for the Canadian International Development Agency (CIDA) as well as by providing advice and technical assistance to help developing countries deal with issues such as desertification and fuelwood shortages; and

- by identifying opportunities to increase the flow of Canadian technologies to the poorest forestry nations, and further developing Forestry Canada's expertise in development forestry through exchanges programs with institutions such as the International Development Research Centre.

4. Develop and expand Canada's intelligence and expertise in international forestry;

- by monitoring and analysing international developments and events to enhance Forestry Canada's knowledge base and ability to address global forestry concerns as well as help the forest sector and the Canadian government better respond to requests and opportunities; and

- by fostering the development of Canadian expertise in selected fields through exchange programs, international assignments and study tours, and participation in international committees.

5. Ensure a more focused representation of Canadian forestry interests at the international level;

- by developing closer working relationships with federal departments and agencies, provincial governments, universities, industry and forestry associations to better co-ordinate and focus Canadian forestry interests at the international level; and

- by maximizing Forestry Canada's participation in various international organizations to ensure the most effective use of available resources and a better representation of the Canadian forest constituency.

6. Support the sustainable development and environmental renewal of global forests;

- by participating in the development of policies to address global forestry issues such as climate change and acid rain;
- by developing and promoting the marketing of environmentally safe pest and fire protection methods, harvesting and processing techniques;

- by promoting key achievements and benefits in assisting industry to deal with a broad range of environmental issues, such as minimizing forest waste; recycling and eliminating dangerous by-products, and using biomass as an alternate energy source; and

- by demonstrating Canada's achievements in its forestry rehabilitation programs and supporting international programs such as the Tropical Forestry Action Plan.

\section{Approaches}

Forestry Canada has used a number of different approaches to help achieve its six principal objectives.

In the area of trade, Forestry Canada has participated in missions to such countries as Brazil, Chile, Argentine, Mexico, and Sweden. It has participated in the R-2000 energy efficient housing program in Japan and a housing demonstration project in China, and has helped promote joint ventures in a number of countries. Cooperation on the development of phytosanitary regulations (e.g., pinewood nematode control) are also aimed at promoting the sale of forest products. Forestry Canada provided expert advice during discussions with the U.S. on the softwood lumber Memorandum of Understanding.

In science, Forestry Canada has a long history of international cooperation in forest research and development. This cooperation includes Forestry Canada's longstanding involvement with the International Union of Forest Research Organisations, covering all aspects of the Union's range of subject areas. It has included such bilateral research agreements as CANUSA, aimed at promoting cooperation between the U.S. and Canada in developing measures to control spruce budworm, and other current bilateral agreements with the USSR, Mexico and China. The focus in these agreements has been on cooperation in such areas as fire control, inventory, remote sensing and forest management. Some useful seed exchanges have taken place and Forestry Canada has been successful in promoting the value of Canadian technology.

Forestry Canada activities have included numerous tours, short-term exchanges of scientists and the hosting of meetings, conferences and seminars. Recently, emphasis has been given to promoting cooperation in such areas as biotechnology and atmospheric pollution (e.g., France, FRG).

For many years Forestry Canada has provided expert assistance in the delivery of forestry development programs administered by the Canadian International Development Agency. Such assistance has been provided particularly for programs dealing with fire protection, inventory, forest product development and harvesting. In recent years Forestry Canada has been closely involved with the establishment of the ASEAN Forest Management Institute and the ASEAN Tree Seed Centre, and for the first time, is the executing agent of a CIDA development project; i.e., Phase II of the ASEAN Seed Centre in Thailand.

To remain up to date on international developments, Forestry Canada has maintained an information base on forest sector developments in other countries, paying special attention to a number of key countries, which have similar forest resource conditions, technology levels or represent a 
potential market for Canadian products and technology. Further access to information has been developed through contacts with Canadian posts abroad, technical missions and attendance at conferences/meetings dealing with forest technology or trade issues. Trends in supply and demand of forest products on the world market are being monitored.

As a responsible member of the world community and to meet its political obligations, Forestry Canada has for many years been involved with international organisations. This involvement has been effected through such organisations as IUFRO and the Timber Committee of the Economic Commission of Europe. Forestry Canada has participated in the affairs of FAO's Committee on Forestry and the various expert Committees under COFO (e.g., Forestry Education, Tree Genetics, Poplar Commission, etc.) Forestry Canada, with other members of the Committee on Forestry (COFO) has continued to stress the importance of Forestry in FAO's budget and through CIDA is actively participating in FAO's Tropical Forestry Action Plan (TFAP).

The North American Forestry Commission, one of six FAO regional commissions, continues to represent an excellent vehicle for cooperation and information exchange between its members, the USA, Canada and Mexico, particularly in such areas as silviculture, fire management, insect and disease control, forest engineering and forest products.

Forestry Canada, through laboratory accreditation, is involved in the OECD scheme for the "control of forest reproductive materials moving in international trade" and is an active member of the forestry division of OECD's International Energy Agency. Forestry Canada has recently taken a more active role in the affairs of the International Tropical Timber Organisation (ITTO) and its Committee deliberations. ITTO is focusing on market transparency of tropical timbers as well as management and conservation aspects of tropical forests.

Commonwealth cooperation is effected through the Commonwealth Agricultural Bureaux International and in particular the Commonwealth Institute for Biological Control to which Forestry Canada provides financial assistance to support insect and disease protection research.

The need is seen more than ever for the sustainable development of forest resources both on a regional and global scale. Forestry Canada has been paying special attention to such issues as atmospheric pollution and has undertaken cooperative work in this area with countries such as the U.S., France and the Federal Republic of Germany. It is also involved with the Inter-governmental Panel on Climate Change and will provide input to the Second World Conservation Strategy report. Involvement in ITTO and FAO's TFAP represent further avenues to promote sustainable development.

Forestry Canada can be proud of its active and productive international program. The Department has contributed importantly to Canada's excellent international reputation in forest technology. Considering that: (i) forest resources can be expected to continue to play a key role in Canada's economy, (ii) environmental issues will become more and more international and global in scope and (iii) the need to access emergencies technology will increase, Forestry Canada's international role will become more and more vital to the Department's overall operations.

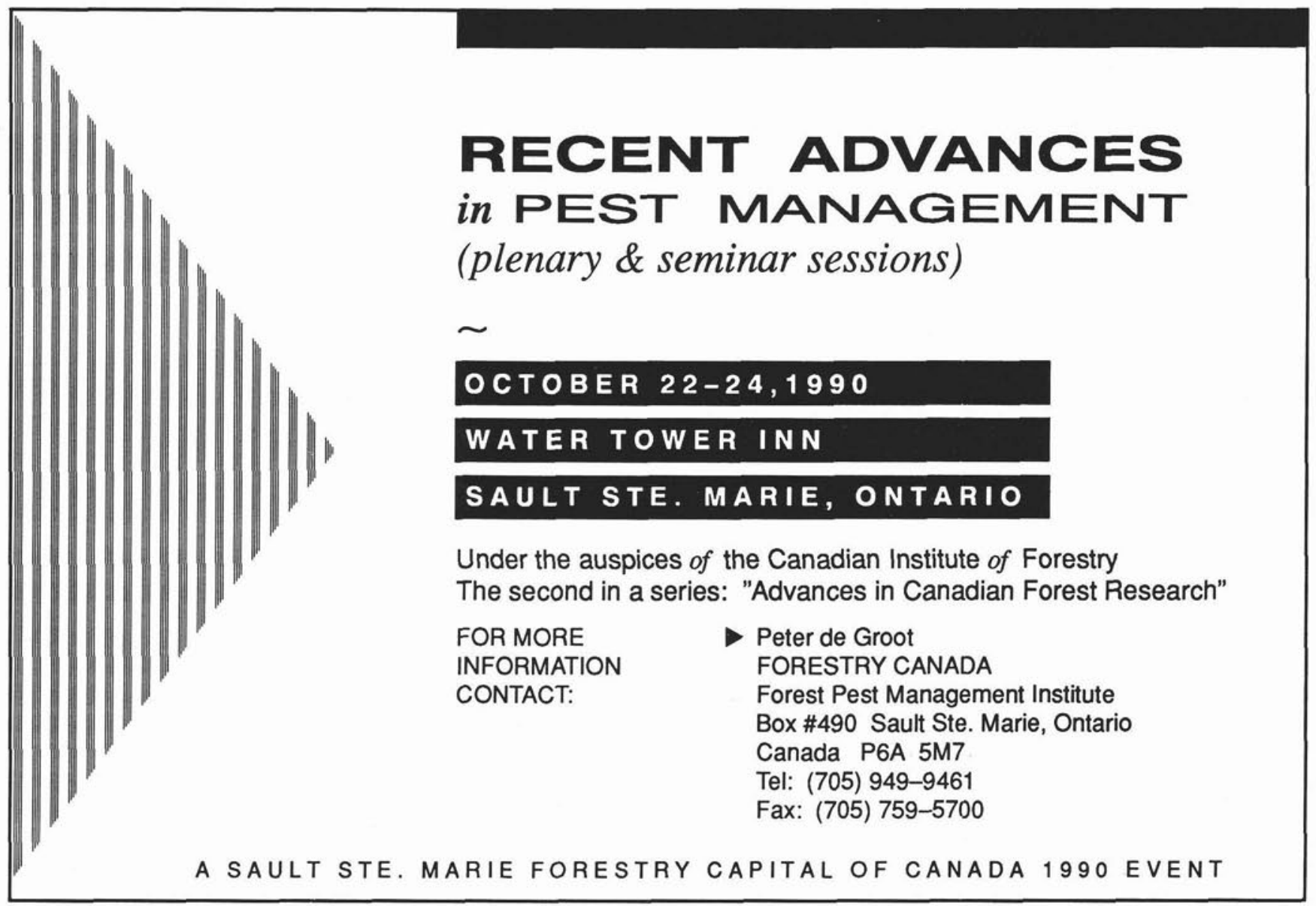

